\title{
Mating, Spore Dissection, and Selection of Diploid Cells in Schizosaccharomyces japonicus
}

\author{
Kanji Furuya ${ }^{1}$ and Hironori Niki ${ }^{2,3}$ \\ ${ }^{1}$ Radiation Biology Center, Kyoto University, Yosida-Konoe-Cho, Sakyo-Ku, Kyoto 606-8501, Japan; ${ }^{2}$ Microbial \\ Genetics Laboratory, Genetic Strains Research Center, National Institute of Genetics, Mishima, Shizuoka \\ 411-8540, Japan
}

Haploid yeast cells mate to form heterozygotes and subsequently undergo meiosis to form spores. This process can be used to produce gene combinations and variants that are useful for genetic analysis. For example, these spores can be used to generate double mutants or to measure genetic distances in a mutational analysis. Here, we describe mating and spore dissection procedures for Schizosaccharomyces japonicus cells. Although the overall procedures resemble those used in Schizosaccharomyces pombe, some differences exist, including the use of EMM2 medium without nitrogen (EMM-N) for mating and the shorter incubation time of $16-20 \mathrm{~h}$ for S. japonicus cells. Furthermore, the S. japonicus zygotes produce eight spores and thus require an "octad" analysis.

\section{MATERIALS}

It is essential that you consult the appropriate Material Safety Data Sheets and your institution's Environmental Health and Safety Office for proper handling of equipment and hazardous materials used in this protocol.

RECIPES: Please see the end of this protocol for recipes indicated by $<R>$. Additional recipes can be found online at http://cshprotocols.cshlp.org/site/recipes.

\section{Reagents}

EMM-N $<\mathrm{R}>$

Prepare EMM-N liquid medium. (EMM-N is EMM2 medium without nitrogen.)

EMM $2<\mathrm{R}>$

Prepare EMM2 agar plates without adenine.

Schizosaccharomyces japonicus strains

Strains are available from the web home of the S. japonicas bioresource center, JapoNet (http://night.nig.ac.jp/ labs/MicroGen/japonet/).

ade6-domK and ade6-domE mutant strains (for selection of diploid cells; see Steps 9-12)

Heterothallic cells of opposite mating types (for induction of meiosis; see Steps 1-8)

YE medium $<\mathrm{R}>$

\footnotetext{
${ }^{3}$ Correspondence: hniki@nig.ac.jp

From the Fission Yeast collection, edited by lain M. Hagan, Antony M. Carr, Agnes Grallert, and Paul Nurse.

(C) 2017 Cold Spring Harbor Laboratory Press

Cite this protocol as Cold Spring Harb Protoc; doi:10.1101/pdb.prot091843
} 


\section{Equipment}

Heat block at $37^{\circ} \mathrm{C}$

Micromanipulator

Sonicator (optional; see Step 11)

Tabletop centrifuge

Test tubes (18-mm)

Vortex

Water bath incubator with shaker at $30^{\circ} \mathrm{C}$

\section{METHOD}

\section{Induction of Meiosis by Nitrogen Starvation}

Nitrogen deficiency is effective for inducing sporulation. The best way to sporulate is by using liquid medium. Portions of this procedure were previously described in Furuya and Niki (2009).

1. Inoculate each mating type of heterothallic cells in $3 \mathrm{~mL}$ of YE liquid medium in $18-\mathrm{mm}$ test tubes, and shake overnight at $30^{\circ} \mathrm{C}$.

The cells must be saturated the next morning.

2. Centrifuge the cells to harvest ( $1100 \mathrm{~g}$ for $1 \mathrm{~min}$ in a tabletop centrifuge at room temperature). Remove the supernatant.

3. Resuspend cells in $0.5 \mathrm{~mL}$ of EMM-N liquid medium. Vortex well.

4. Prepare a new test tube (18-mm diameter) with $0.5 \mathrm{~mL}$ of EMM-N liquid medium, and add $0.05 \mathrm{~mL}$ of both mating types of heterothallic cells.

5. Incubate the mixture of heterothallic cells for $16-20 \mathrm{~h}$ at $30^{\circ} \mathrm{C}$.

It is not necessary to shake the mixture in the test tube; the tube can simply be left standing for incubation. Overnight incubation in EMM-N liquid medium at $30^{\circ} \mathrm{C}$ provides a sufficient number of spores to work on.

6. Check for sporulation by microscopy.

A dumbbell-shaped ascus includes eight spores.

See Troubleshooting.

7. Harvest and centrifuge the cells in a tabletop centrifuge $(1100 \mathrm{~g}$ for $1 \mathrm{~min}$ at room temperature). Add $0.1 \mathrm{~mL}$ of $1 \mathrm{mg} / \mathrm{mL}$ Zymolyase $100 \mathrm{~T}$ to the cell pellet. Place in a heat block for 5 min at $37^{\circ} \mathrm{C}$.

Fresh asci are hard to dissect. Digesting the ascus wall with Zymolyase $100 \mathrm{~T}$ helps to subsequently release the eight spores for dissection using the micromanipulator needle. If the mixture is standing at room temperature for an extended period of time, the asci are autonomously lysed so that the spores are released. Spore viability is maintained for $1 \mathrm{wk}$ at $4^{\circ} \mathrm{C}$.

8. Spread the ascospores onto YE 2\% agar plates for dissection. Perform spore dissection using a micromanipulator.

\section{Selection of Diploid Cells}

The ade6-domK and ade6-domE alleles show interallelic complementation when they are simultaneously expressed in the same cell. As with S. pombe ade6-M210 and ade6-M216, this facilitates the construction of diploid cells (Furuya and Niki 2011).

9. Mix the two ade6 mutants, one of each mating type, following Steps 1-4. 
K. Furuya and H. Niki

10. Incubate the mixture for $5 \mathrm{~h}$ at $30^{\circ} \mathrm{C}$.

Because heterozygotes are formed in 4-5 h, cell aggregation, namely sexual flocculation, can be seen in the tube.

11. Spread cells in the mixture onto EMM2 agar plates lacking adenine.

If necessary, aggregated cells can be gently sonicated.

12. Check for diploid cells under a microscope.

The diploid cells are twice as large as the haploid cells.

\section{TROUBLESHOOTING}

Problem (Step 6): Some of the selected clones of diploid cells lose their ability to sporulate.

Solution: Multiple clones of diploid cells should be isolated and tested.

\section{RECIPES}

EMM2

Reagent

Quantity (for 1 L)

Final concentration

Ammonium chloride

Potassium hydrogen phthalate

$\mathrm{Na}_{2} \mathrm{HPO}_{4}$

Glucose

Salt stock $(50 \times)$

Vitamins $(1000 \times)$

Minerals $(10,000 \times)$

$\mathrm{H}_{2} \mathrm{O}$

$\begin{array}{rr}5 \mathrm{~g} & 93.5 \mathrm{~mm} \\ 3 \mathrm{~g} & 14.7 \mathrm{~mm} \\ 2.2 \mathrm{~g} & 15.5 \mathrm{~mm} \\ 20 \mathrm{~g} & 111 \mathrm{~mm} \\ 20 \mathrm{~mL} & 1 \times \\ 1 \mathrm{~mL} & 1 \times \\ .1 \mathrm{~mL} & 1 \times\end{array}$

Prepare $1 \mathrm{~L}$ of EMM2 by combining the reagents above. To prepare solid medium, include agar $(20 \mathrm{~g} / \mathrm{L})$. Sterilize by autoclaving at $10 \mathrm{psi}$ for $10 \mathrm{~min}$ (for liquid medium) or $15 \mathrm{~min}$ (for solid medium). (For liquid medium, low pressure and a short cycle is essential to avoid caramelization of glucose and breakdown of vitamins and minerals. For live cell imaging, filter-sterilized medium has lower background fluorescence than autoclaved medium. Use a $0.22-\mu \mathrm{m}$ pore size for filtration.) Store at $4^{\circ} \mathrm{C}$. If desired, add $12 \mu \mathrm{M}$ thiamine $(364 \mu \mathrm{L}$ of a filter-sterilized stock solution of $10 \mathrm{mg} / \mathrm{mL}$ on $\mathrm{H}_{2} \mathrm{O}$ ) after autoclaving to fully repress expression from $n m t 1$-derived promoters (Maundrell 1990).

$E M M-N$

Reagent

Quantity (for 1 L)

Final concentration

Potassium hydrogen

$3 \mathrm{~g}$

$14.7 \mathrm{~mm}$

phthalate

$\mathrm{Na}_{2} \mathrm{HPO}_{4}$

$2.2 \mathrm{~g}$

$20 \mathrm{~g}$

$15.5 \mathrm{mM}$

Glucose

$20 \mathrm{~mL}$

$111 \mathrm{~mm}$

Salt stock $(50 \times)<\mathrm{R}>$

$1 \mathrm{~mL}$

$1 \times$

Vitamins $(1000 \times)<\mathrm{R}>$

$0.1 \mathrm{~mL}$

$1 \times$

Minerals $(10,000 \times)<\mathrm{R}>$

to $1 \mathrm{~L}$

$\mathrm{H}_{2} \mathrm{O}$

Prepare 1 L of EMM-N (EMM2 without nitrogen) (Nurse 1975) by combining the reagents above. To prepare solid medium, include agar $(20 \mathrm{~g} / \mathrm{L})$. Sterilize by autoclaving at $10 \mathrm{psi}$ for $10 \mathrm{~min}$ (for liquid medium) or $15 \mathrm{~min}$ (for solid medium). Store at $4^{\circ} \mathrm{C}$. If desired, add $12 \mu \mathrm{m}$ thiamine $(364 \mu \mathrm{L}$ of a filter-sterilized stock solution of $10 \mathrm{mg} / \mathrm{mL}$ on $\mathrm{H}_{2} \mathrm{O}$ ) after autoclaving to fully repress expression from nmt1-derived promoters (Maundrell 1990). 
Minerals $(10,000 \times)$

Reagent

Boric acid

$\mathrm{MnSO}_{4}$

$\mathrm{ZnSO}_{4} \cdot 7 \mathrm{H}_{2} \mathrm{O}$

$\mathrm{FeCl}_{2} \cdot 6 \mathrm{H}_{2} \mathrm{O}$

Molybdic acid

KI

$\mathrm{CuSO}_{4} \cdot 5 \mathrm{H}_{2} \mathrm{O}$

Citric acid

Store at $4^{\circ} \mathrm{C}$.

Salt Stock (50x)

Reagent

Quantity (for 1 L)

$52.5 \mathrm{~g}$

$0.735 \mathrm{~g}$

$50 \mathrm{~g}$

$2 \mathrm{~g}$

$\mathrm{MgCl}_{2} \cdot 6 \mathrm{H}_{2} \mathrm{O}$

$\mathrm{CaCl}_{2} \cdot 2 \mathrm{H}_{2} \mathrm{O}$

$\mathrm{KCl}$

$\mathrm{Na}_{2} \mathrm{SO}_{4}$

Store at $4^{\circ} \mathrm{C}$.

Vitamins (1000x)

Reagent

Quantity (for 1 L)

Pantothenic acid

Nicotinic acid

Inositol

Biotin

Store at $4^{\circ} \mathrm{C}$.

\section{YE Medium}

Reagent Quantity (for 1 L)

$30 \mathrm{~g}$

$20 \mathrm{~g}$
Yeast extract

Glucose

Agar (for plates only)

$1 \mathrm{~g}$
$10 \mathrm{~g}$

$10 \mathrm{~g}$

$10 \mathrm{mg}$

$\begin{array}{rr}5 \mathrm{~g} & 0.5 \% \\ 30 \mathrm{~g} & 3 \% \\ 20 \mathrm{~g} & 2 \%\end{array}$

Final concentration

$80.9 \mathrm{~mm}$

$23.7 \mathrm{mM}$

$13.9 \mathrm{~mm}$

$7.40 \mathrm{~mm}$

$2.47 \mathrm{~mm}$

$6.02 \mathrm{~mm}$

$1.60 \mathrm{~mm}$

$47.6 \mathrm{~mm}$
Final concentration

$0.26 \mathrm{M}$

$4.99 \mathrm{~mm}$

$0.67 \mathrm{M}$

$14.1 \mathrm{~mm}$

Store for up to $3 \mathrm{mo}$ at room temperature, or for up to $6 \mathrm{mo}$ at $4^{\circ} \mathrm{C}$.

\section{REFERENCES}

Furuya K, Niki H. 2009. Isolation of heterothallic haploid and auxotrophic mutants of Schizosaccharomyces japonicus. Yeast 26: 221-233.

Furuya K, Niki H. 2011. Construction of diploid zygotes by interallelic complementation of ade6 in Schizosaccharomyces japonicus. Yeast 28: 747-754.
Maundrell K. 1990. $n m t 1$ of fission yeast. A highly transcribed gene completely repressed by thiamine. J Biol Chem 265: 10857-10864.

Nurse P. 1975. Genetic control of cell size at cell division in yeast. Nature 256: 547-551.

Final concentration

$4.20 \mathrm{~mm}$

$81.2 \mathrm{~mm}$

$55.5 \mathrm{mM}$

$40.8 \mu \mathrm{M}$

Final concentration $(\mathrm{w} / \mathrm{v})$

$\begin{array}{lr}5 \mathrm{~g} & 0.5 \% \\ 30 \mathrm{~g} & 3 \% \\ 20 \mathrm{~g} & 2 \%\end{array}$

$0.5 \%$

$2 \%$ 


\section{Mating, Spore Dissection, and Selection of Diploid Cells in Schizosaccharomyces japonicus}

Kanji Furuya and Hironori Niki

Cold Spring Harb Protoc; doi: 10.1101/pdb.prot091843 originally published online July 21, 2017

\begin{tabular}{rc}
$\begin{array}{r}\text { Email Alerting } \\
\text { Service }\end{array}$ & Receive free email alerts when new articles cite this article - click here. \\
\hline $\begin{array}{c}\text { Subject } \\
\text { Categories }\end{array}$ & $\begin{array}{c}\text { Browse articles on similar topics from Cold Spring Harbor Protocols. } \\
\text { Genetics, general (374 articles) } \\
\text { Yeast (288 articles) }\end{array}$ \\
\hline
\end{tabular}

